\title{
Spatial and temporal dynamics of water isotopes in the riverine-marine mixing zone along the German Baltic Sea coast
}

\author{
Bernhard Aichner ${ }^{1}$, Timo Rittweg ${ }^{1}$, Rhena Schumann², Sven Dahlke ${ }^{3}$, Svend Duggen ${ }^{4}$, and \\ David Dubbert ${ }^{1}$ \\ ${ }^{1}$ Leibniz-Institute of Freshwater Ecology and Inland Fisheries in the Forschungsverbund \\ Berlin eV \\ ${ }^{2}$ University of Rostock \\ ${ }^{3}$ University of Greifswald \\ ${ }^{4}$ A. P. Møller Skolen
}

January 20, 2022

\begin{abstract}
River estuaries are characterized by mixing processes between isotopically depleted freshwater inflows and isotopically more enriched marine water masses. Therefore, they often show linear correlation between salinity and water isotopes $(\delta 18 \mathrm{O}$ and $\delta 2 \mathrm{H}$ values). Here we evaluated spatial and seasonal isotope dynamics along three estuarine lagoon transects at the northern German Baltic Sea coast. The data show strong seasonality of isotope values even at locations located furthest from the river mouths. They further reveal a positive and linear salinity-isotope correlation in spring, but hyperbolic and partially even reverse correlation in summers. We conclude that additional physical processes, such as evaporation from the shallow lagoons, overprint the two-phase mixing correlation during summers. Understanding of those water isotope dynamics are crucial in context of ecological studies, for example when interpreting oxygen and hydrogen isotope data in aquatic organisms that depend on ambient estuarine waters.
\end{abstract}

\section{Introduction}

The water cycle, or hydrological cycle, refers to the movement of water molecules throughout the globes geological, biological and ecological compartments. Major constituents of this cycle are water evaporating from the oceans, transportation of vapor to continental realms, re-condensation to rain droplets, and flow back via groundwater and surface flow towards the ocean. The varying physical properties, specifically the different weights of stable oxygen and hydrogen isotopes of the water molecule $\left({ }^{16} \mathrm{O},{ }^{17} \mathrm{O},{ }^{18} \mathrm{O},{ }^{1} \mathrm{H},{ }^{2} \mathrm{H}\right)$, lead to isotope fractionation during all these processes (H. Craig, 1961; Dansgaard, 1964). As a consequence, the isotopic signature of water in both the liquid and the vapor phase is characterized by spatial and temporal variability, and in principal is depleted of the heavier isotopes in water vapor and continental freshwater, compared to the ocean water (Gat, Gonfiantini, \& (Eds), 1981). For this reason, mixing processes in the transitional zone between the riverine/freshwater and marine/saline realm lead to linear relationships between salinity and water isotopes in those systems, as observed in multiple river estuaries around the globe (Barrie, Worden, Barrie, \& Boyce, 2015; Chamberlayne, Tyler, \& Gillanders, 2021; Ingram, Conrad, \& Ingle, 1996; Mohan \& Walther, 2015; Price, Skrzypek, Grierson, Swart, \& Fourqurean, 2012; Swart \& Price, 2002).

In precipitation, isotopes exhibit a seasonal signal, with lower / higher values in the cold and warm season, respectively (Bowen \& Revenaugh, 2003). This seasonal partitioning of isotopes provides an opportunity to model spatial dynamics of isotopes across a landscape, riverscape, or seascape (Aron et al., 2021; Brennan, Cline, \& Schindler, 2019; Orlowski, Kraft, Pferdmenges, \& Breuer, 2016). Riverine and lacustrine systems 
reflect this signal (B. Aichner et al., 2021; Dutton, Wilkinson, Welker, Bowen, \& Lohmann, 2005; Halder, Terzer, Wassenaar, Araguas-Araguas, \& Aggarwal, 2015; Ogrinc, Kanduc, Stichler, \& Vreca, 2008; Reckerth, Stichler, Schmidt, \& Stumpp, 2017), but the seasonal amplitude is attenuated and timing of the signal delayed by 1-3 months (Bittar et al., 2016; Jasechko, Kirchner, Welker, \& McDonnell, 2016; Reckerth et al., 2017; Rodgers, Soulsby, Waldron, \& Tetzlaff, 2005). The reasons for the time delay between precipitation and river/lake water isotopes, and the smaller seasonal amplitude of the latter, can be attributed to multiple catchment characteristics and processes. Crucial influencing factors on how fast a precipitation isotope signal is transferred into fluvial systems are the flow regime of rivers, and the area, topography and geology of their catchments (Maloszewski, Rauert, Trimborn, Herrmann, \& Rau, 1992; McGuire et al., 2005; Rodgers et al., 2005; Sklash, Farvolden, \& Fritz, 1976) .

In water bodies with high residence time of the water, such as large and/or voluminous lakes or in the marine realm, the seasonal $\delta^{18} \mathrm{O}$ and $\delta^{2} \mathrm{H}$ variability decreases. Instead mixing processes of water from different sources with variable isotopic signatures, become more dominant on the actual isotopic signature (Benetti, Reverdin, Aloisi, \& Sveinbjornsdottir, 2017; Harmon Craig \& Gordon, 1965; Frew, Dennis, Heywood, Meredith, \& Boswell, 2000). The North Sea, for example, is influenced by both North Atlantic water with high salinity, entering the North Sea basin from the northeast, and inflow of brackish water and freshwater, derived from the Baltic Sea and from rivers, respectively (Harwood, Dennis, Marca, Pilling, \& Millner, 2008). The Baltic Sea, in turn experiences occasional inflow intrusion from the North Sea (higher $\delta^{18} \mathrm{O}$ and $\delta^{2} \mathrm{H}$ values), but also constantly receives freshwater discharge from rivers (lower $\delta$-values). For these reasons water isotopes show a strong positive correlation with salinity in both the Baltic Sea and North Sea (Ehhalt, 1969; Frohlich, Grabczak, Rô, \& bDski, 1988; Jefanova et al., 2020; Richter \& Kowski, 1990; Torniainen et al., 2017) .

Isotope signatures of the ambient water are mirrored in the local fauna and flora, e.g. by plants or fish which depend on estuarine water. For example, fish incorporate elements from ambient water into their body structures, for example (ear bones) (Zanden, Soto, Bowen, \& Hobson, 2016). These structures form through precipitation from the water the fish currently lives in, and as such, mirror to some extent the current isotopic profile of the water (Patterson, Smith, \& Lohmann, 1993). In recent years, oxygen isotopic ratios of otoliths have been commonly used in studies of migration and geolocation of fish, by deriving predictive surfaces, ie. isoscapes of large-scale water isotope data, in order to retrospectively predict the whereabouts of migrating fish (Torniainen et al., 2017; Trueman, Mackenzie, \& Palmer, 2012), and to assign fish to discrete, geographically segregated stocks (Matta, Black, \& Wilderbuer, 2010). With respect to aquatic plants or algae, their cellular lipid compounds have been shown to track the hydrogen isotopic signature of the ambient water, but with a potential additional influence of varying salinity (Bernhard Aichner, Hilt, Périllon, Gillefalk, \& Sachse, 2017; Häggi, Chiessi, \& Schefuß, 2015; He, Nemiah Ladd, Saunders, Mead, \& Jaffé, 2020; Ladd \& Sachs, 2015, 2017; Sachs \& Schwab, 2011; Schouten et al., 2006). These dependencies have frequently been applied in paleoclimatic studies, i.e. for reconstruction of past hydrological conditions and salinities (e.g. (Bernhard Aichner et al., 2019; Leduc, Sachs, Kawka, \& Schneider, 2011; Meer et al., 2007)).

Knowledge and understanding about water isotopic gradients has great potential to facilitate application and interpretation of oxygen and hydrogen isotopic compositions in biogenic carbonates and plant lipids. In this study we analysed water isotope dynamics in estuarine river and lagoon systems along the northern German Baltic Sea coast. Main questions of this study are: 1) how far are seasonal isotope signals in rivers transmitted into Baltic Sea estuarine systems? 2) what are the major processes behind the observed gradients? 3) are water isotopes a predictor for salinity in the riverine-marine mixing zone? The major aim is to understand the underlying control mechanisms on seasonal and spatial water isotope variability in this study area, which is essential when fish and plant isotope data are interpreted in ecological and biogeochemical studies.

\section{Study area}

The northeastern German coast of the Baltic Sea is basically a flooded glacial moraine landscape. It is characterized by extensive bays, shallow lagoons (the boddens) and marine inlets, which form the mixing 
zone between rivers and the marine realm (Correns, 1977; Schwarzer, Ricklefs, Bartholomä, \& Zeiler, 2008). These zones are characterized by hydrologic events which in turn affect biochemical characteristics of the ecosystem. For example they react sensitively both to discharge pulses from rivers and inflow events from the marine side after storms (Gocke, Rheinheimer, \& Schramm, 2003). Further, a dense net of water management structures, such as water retention flaps, partially attenuate freshwater flow from creeks into the lagoons. Here, automatic ones will release water from creeks when the lagoons are low while some manual flaps exist, which are operated by hand (Funkel, 2004) .

For this study, water samples were taken along three transects, encompassing salinity gradients (Figs. 1 and 2; Supplementary Tables S1 and S2):

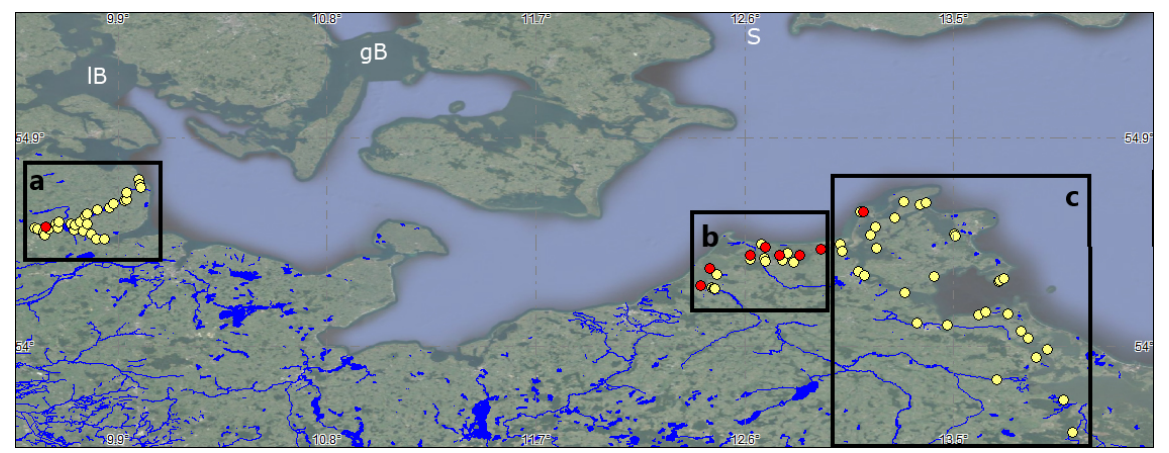

Fig. 1: Transect sample points at a) Schlei, b) Darß-Zingster Bodden Chain (DZBC), and c) Eastern Transect (Stettiner Haff - Peenestream - Greifswalder Bodden - Rügener Boddens). Red circles: time-series sampling. Yellow circles: seasonal sampling. lB: Little Belt. gB: Great Belt. S: øresund. Sampling points are listed in Supplementary Tables S1 and S2.

a) the Schlei estuarine (Figs 1 and 2a) is a flooded sub-glacial channel, extending ca. $42 \mathrm{~km}$ from the major Baltic Sea coast line towards the inlands. The inner Schlei comprises the two larger basins of the "Kleine Breite" and "Große Breite", while the outer Schlei at some sections resembles a wider river. Adjacent, several "Noors", i.e. water bodies similar to lakes, are connected to the main Schlei often by just narrow outlets. The Schlei has one medium sized inflow, the Füsinger Au at Kleine Breite, and several small creeks entering along the whole length of the water body. The salinity gradient is linearly increasing from almost 0-3 psu at the inner Schlei (Burgsee and Kleine Breite) towards values of ca. 15-20 psu near the outflow to the Baltic Sea (Gocke et al., 2003; Grupe, Heinrich, \& Peters, 2009; LLUR. Schleswig-Holstein, 2001; Seiß, 2014). This gradient is seasonally influenced by relatively high freshwater discharge in winter and spring compared to summers. Additionally, episodic sea level changes by $\pm 0.5-1.5 \mathrm{~m}$, caused by strong winds, lead to rapid movement of water masses within the Schlei, which superimposes the salinity gradient (Schulz, 1979). Saltwater intrusion events, from the North Sea into the Baltic Sea (Volker Mohrholz, 2018) (Fig 3) similarly have the potential to increase salinity values in the outer Schlei, as visible for March 2020 in contrast to July 2020 (Fig. 2a).

b) the Darß-Zingst Bodden chain (DZBC) is a system of several shallow water basins, which mostly do not exceed 2-3 m water depth (Figs. 1 and $2 \mathrm{~b}$ ). The rivers Recknitz and Barthe are major inflows and there are two outflows towards the Baltic Sea, which lie close to each other at the easternmost end of the Darß-Zingst peninsula. The salinity gradient is covering the range from almost freshwater conditions near the Recknitz and Barthe inflows to ca 10 psu near the outflows (Chubarenko, Chubarenko, \& Baudler, 2005). Those reflect the salinity values in the adjacent Baltic Sea, which are lower than in the more western realms (where the Schlei is situated), but likewise influenced by salt water intrusion events (Fig. 2b). The DZBC can be divided into an inner / western part (Saaler Bodden and Bodstedter Bodden), which is mainly influenced by riverine inflows and an outer / eastern part (Barther Bodden and Grabow) which is more susceptible to Baltic water inflow during conditions of east winds (Schumann, Baudler, Glass, Dümcke, \& Karsten, 2006). 
The two parts are connected by the Zingster Stream (ZS), a narrow and deep water channel located in the central bodden chain.

c) the easternmost transect reaches from the Stettiner Haff, via the Greifswalder Bodden to the multiple lagoons which form the western and northern bodden chains around the isle Rügen (WRBC and NRBC) (Figs 1 and 2c). While the covered salinity gradient is similar than in the DZBC (i.e. 0 - ca. 10 psu), several inflows and connections to the Baltic Sea create a more dynamic system, in exchange with marine water widely overprinting the effects of freshwater inflow by rivers (Bachor, 2005; Correns \& Jäger, 1979; H. Hübel \& Dahlke, 1999; Helmut Hübel, Wolff, \& Meyer-Reil, 1998)). The Stettiner Haff is strongly under influence of the Oder river, which contributes $>95 \%$ of the riverine discharge along the northeastern German Baltic Sea coastline (Richter \& Kowski, 1990). Salinity is gradually increasing between the Stettiner Haff, along the Peene-Stream towards the Greifswalder bodden (Fig. 2c) (Lampe, 1999). The latter is a larger basin of max $13.5 \mathrm{~m}$ depth which is separated to the open Baltic Sea by the "Greifswalder Boddenrandschwelle", a glacial terminal moraine which builds a just $1-2.5 \mathrm{~m}$ deep shallow. The Greifswalder Bodden is connected to the WRBC by the Strela Sound, which terminates in the Vitter Bodden next to Hiddensee island. The same bodden can be seen as terminal basin of the inner or northern Rügen bodden chain (NRBC; reaching from Kleiner Jasmunder Bodden via Großer Jasmunder, Breeger, and Wieker Bodden), which is characterized by a salinity gradient from 0 to ca. 10 psu, comparable as in the DZBC (Birr; Ulrich Schiewer, 2008).

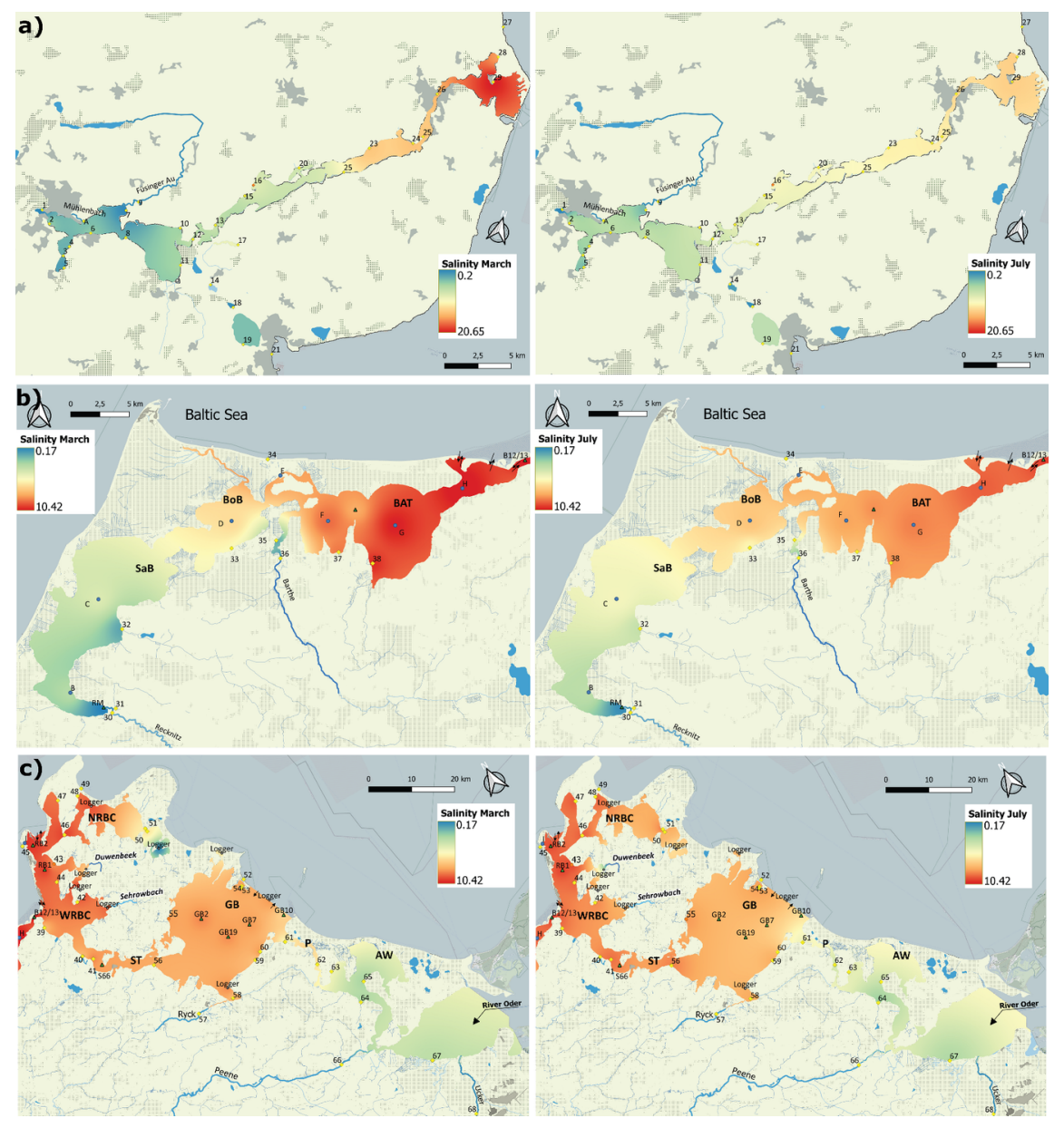

Fig. 2: Salinity in March (left) and July (right) 2020, in the Schlei (a), DZBC (b) and Rügener boddens (c). Panels a - c refer to subregions as indicated in Figure 1. Blue circles A-I: sampling points for time-series. 
Yellow circles \#1-68: shore samples. Green triangles indicate LUNG monitoring point with data included into salinity interpolation. Arrows indicate exchange points with Baltic Sea water. SaB: Saaler Bodden. BoB: Bodstedter Bodden: BAT: Barther Bodden and Grabow. WRBC: Western Rügen Bodden Chain. NRBC: Northern Rügen Bodden Chain. GB: Greifswalder Bodden. P: Peene Stream. AW: Achterwasser.

\section{Material and methods}

\subsection{Water sampling}

Water samples were taken along transects (yellow dots in Fig. 1) in June 2019 (lower density of sampling points), March 2020, and July 2020. They were collected close to shores with a pipette from ca. 40-60 cm below water surface and directly transferred into a GC-vial. The vials were instantly closed and stored in a cooling box, before being placed in a fridge until further procession.

At selected spots, time-series were sampled 2-4 weekly (A: Schlei, A. P. Møller Skolen Schleswig; E: Zingster Strom, Biological Station; I: Vitter Bodden, Kloster/Hiddensee) or monthly (B-D, F-G: Zingster Bodden) from March 2020 to March 2021. Samples from A and I were taken accordingly to shore samples, while samples B-H were taken in deep parts of the boddens, close to buoys marking long-term monitoring locations. For the latter, a Limnos water sampler was used to obtain $2 \mathrm{~L}$ samples from 0.5-1.0 $\mathrm{m}$ depth below water surface, of which $1.5 \mathrm{~mL}$ were transferred into GC vials.

\subsection{Water chemical parameters}

Water chemical parameters were measured in situ at shore transect and time series sampling spots A and I, using a Multi 3630 IDS multiparameter device (WTW, Weilheim, Germany), equipped with a WTW TetraCon 925 electrical conductivity measuring cell. At the A. P. Møller Skolen salinity and temperature

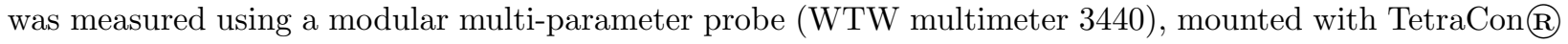
925-P and MPP 930 IDS electrical conductivity cells. Before each application the cells were calibrated with E-Set Trace 0.01 M KCl calibration solution based on PTB/NIST. For samples from DZBC-timeseries (spots B-H), a WTW 1970i conductivity meter and TetraCon 325 measuring cell were used to analyse electrical conductivity / salinity in the laboratory.

Salinity maps (Fig. 2) were produced in QGIS 3.14 using the inverse distance weighted interpolation tool with a squared weighting coefficient for the sampling periods March and July 2020. Herefore, the in-situ measured salinity values were used for spatial interpolation, in combination with data derived from monthly monitoring stations of local authorities (LUNG; Landesamt für Umwelt, Naturschutz, Geologie of the German State Mecklenburg-Vorpommern) (Fig. 2). For March 2020, some additional values were derived from HOBO U24002-C salinity loggers (Onset, Bourne, USA), which were installed at different locations around the Rügener boddens. Data were only interpolated within the riverine-marine mixing zone, while the open Baltic Sea was excluded.

\subsection{Isotope measurement}

Water samples were filtered $\left(0.2 \mu \mathrm{m}\right.$ cellulose acetate) prior to analysis of stable isotopes $\left(\delta^{18} \mathrm{O}\right.$ and $\delta^{2} \mathrm{H}$ values) in the water isotope lab at IGB Berlin, using a Picarro (Santa Clara, CA, USA) L2130-i cavity ring-down spectrometer (CRDS). Measurements were routinely checked for organic contamination using the Picarro ChemCorrect software.

Isotope values and standard deviations are based on six replicate measurements of each sample, discarding the first three measurements to account for memory effects. In house criteria excluded all injections with a water SD higher than $400 \mathrm{ppm}$ or water amount deviation greater than $3000 \mathrm{ppm}$ to furthermore improve precision.

For instrument calibration we used 3 laboratory standards for each group of 24 samples: $\mathrm{L}\left(\delta^{18} \mathrm{O}-17.86 \delta^{2} \mathrm{H}\right.$ -109.91 and $\delta^{2} \mathrm{H}-72.81$ and $\delta^{2} \mathrm{H} 0.29\left(\delta^{18} \mathrm{O}-7.68\right.$ used as quality and drift control after every 6 samples. All lab standards were referenced against primary measurement standards: VSMOW2 (Vienna Standard Mean Ocean Water 2), GRESP (Greenland Summit Precipitation), and SLAP2 (Standard Light Antarctic 
Precipitation 2) from the IAEA (International Atomic Energy Agency, Vienna International Centre, A-1400 Vienna, Austria).

\section{Results and discussion}

\subsection{Seasonal control on water isotopes (time series)}

Schlei (Kleine Breite, Schleswig)

At the inner Schlei, water isotopes show a seasonal trend (higher/lower values in summer/winter) while in contrast salinities were relatively constant (ca. $6-7 \mathrm{psu}$ ) at most measuring days within the sampling period $\left(26^{\text {th }}\right.$ March $2020-16^{\text {th }}$ March 2021) (Fig. 3). Exceptions were two samples from $26^{\text {th }}$ March 2020 and $19^{\text {th }}$ Feb 2021, which showed decreased salinity values of $3.5-4.3 \mathrm{psu}$. Those are mirrored by lower $\delta$-values in water samples collected at those two days.

During, both February/March 2020 and February 2021, major storms lead to increased precipitation and consequently higher surface runoff of rivers and creeks discharging into the Schlei (Figs. 2a and 3). The sampling spot $\mathrm{A}$ is located about $5 \mathrm{~km}$ west of the mouth of the river Füsinger $\mathrm{Au}$, the annual freshwater input of which is about twice the total water volume of the entire Schlei (Gocke et al., 2003). Further it is located ca. $100 \mathrm{~m}$ eastwards the inflow of the small creek Mühlenbach, and therefore susceptible to major discharge events, delivering freshwater with lower $\delta$-values.

The maximum $\delta$-values are reached in September and early October (Fig. 3), i.e. 1-2 months delayed to maximum air and water temperatures. On the other hand it is synchronous to maximum $\mathrm{O}_{2}$-depletion (i.e. minimum $\mathrm{O}_{2}$-concentration) at the sampling spot. The mechanistic relationship between phytoplankton blooms, local oxygen depletion and oversaturation, carbonate precipitation, and $\mathrm{pH}$ values, and their effects on oxygen isotopes in lacustrine waters have long been debated (e.g. (Dietzel, Tang, Leis, \& Köhler, 2009; Li et al., 2020; Quay et al., 1995)). Likewise, an effect of this parameters on the measured $\delta^{18} \mathrm{O}$ values at Schlei cannot be fully excluded, but do not explain synchronous trends in $\delta^{2} \mathrm{H}$ values. 

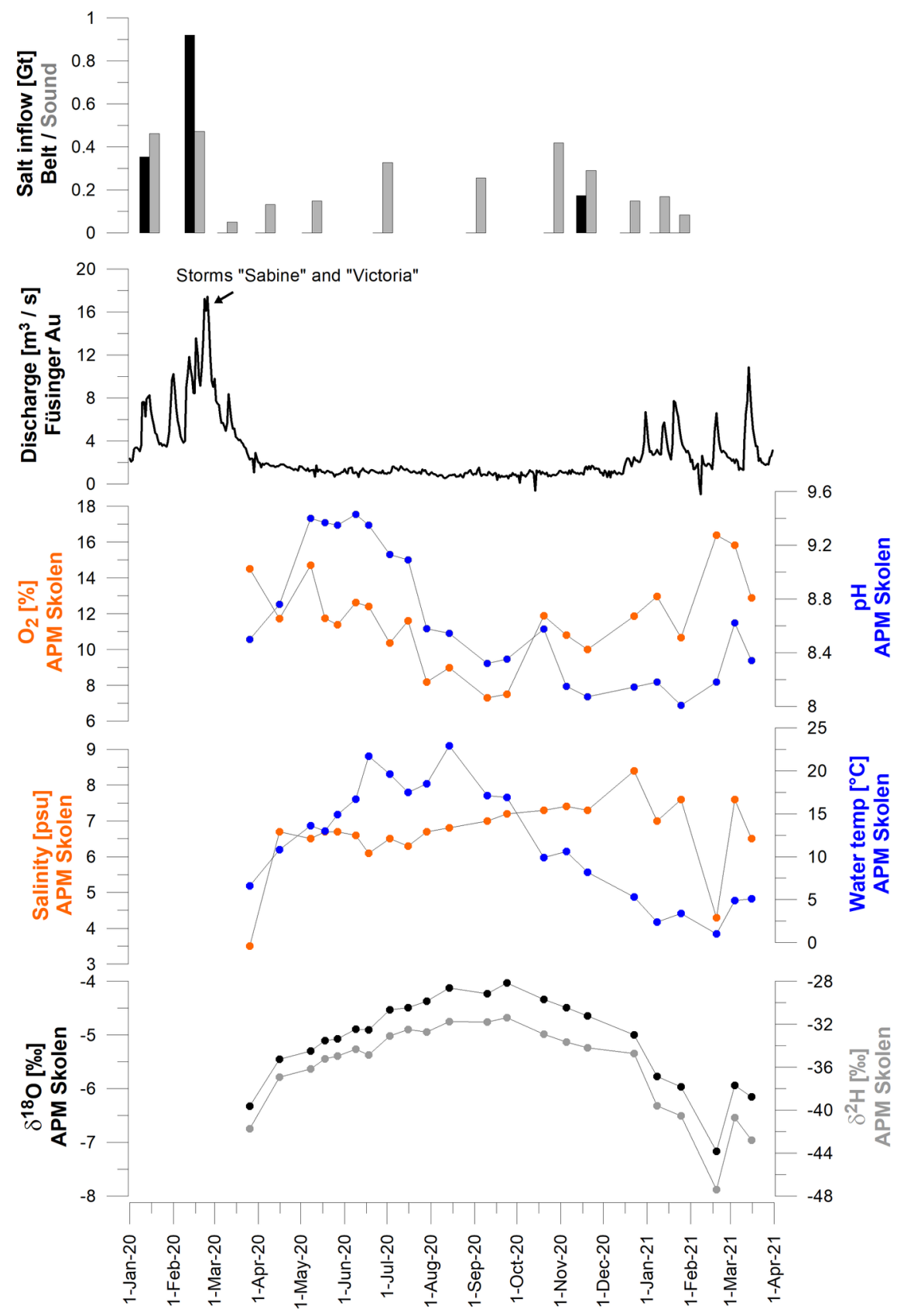

Fig. 3: Time series of $\delta^{2} \mathrm{H} / \delta^{18} \mathrm{O}$ values in water samples collected between $26^{\text {th }}$ March 2020 to $16^{\text {th }}$ March 2021 at A. P. Møller Skolen (APM Skolen), Schleswig (Kleine Breite, Schlei; sampling point A; Fig. 2a), in comparison to salinity, water temperature, $\mathrm{pH}$. Data of daily mean values of water discharge derived from the major inflowing river Füsinger Au (LLUR, 2022). Major Baltic Sea salt inflow events at Great Belt and Øresund from (V. Mohrholz, 2018).

\section{Zingster Stream and boddens}

In contrast to the Kleine Breite (Schlei), at Zingster Stream (sampling point E), the salinity values exhibited a more pronounced seasonal trend, with lower $\delta$-values in winter/spring and higher values in summers (Fig. 
4). This is a common pattern in Baltic Sea lagoons and related to the seasonal discharge pattern of inflowing rivers (Cyberski, Wróblewski, \& Stewart, 2000) (Fig. 4). Short-term salinity fluctuations on the other hand can be explained by influence of different water masses from either the eastern or western side of the Zingster Stream, which is controlled by wind direction and water level differences (Schumann et al., 2006). The water isotope values mirror the seasonal salinity trend throughout the studied time period $\left(24^{\text {th }}\right.$ March $2020-9^{\text {th }}$ March 2021; Fig. 4), i.e. show lower values in winter/spring and higher in summers (Fig. 4). Comparable to the Schlei, the correlations between water isotopes and water / air temperature, as well as $\mathrm{O}_{2}$-saturation cannot rule out effects of these parameters onto $\delta$-values. This is especially true for lower temperatures in the colder winter $(2020 / 21)$ compared to the mild winter $(2019 / 20)$, which could explain the lower $\delta$-values in Jan-March 2021.

A similar seasonal trend in water isotopes as in Zingster Stream is discovered at all sampling locations at the DZBC, i.e. from the inflow of the Recknitz (sampling point B) to the outflow from the boddens towards the Baltic Sea (sampling point H) (Fig. 5). The decreasing influence of freshwater inflow along this transect is clearly visible at increasing salinities, despite the actual seasonal salinity trends are different in the outer boddens (F, G, H) compared to the innermost boddens (B, C) (Fig. 5a). Close to the outflow towards the Baltic Sea (point H), high salinities up to 14 psu were observed in February 2020 and March 2021. Those areas are more susceptible to salinity changes of the Baltic Sea, which in turn are influenced by salt water intrusion events from the North Sea, via the Little Belt, Great Belt and Øresund (Volker Mohrholz, 2018) (Fig. 1). Especially in February 2020 large amounts of salt water was driven by two major storms into the Baltic Sea (V. Mohrholz, 2018) (Fig. 3). 

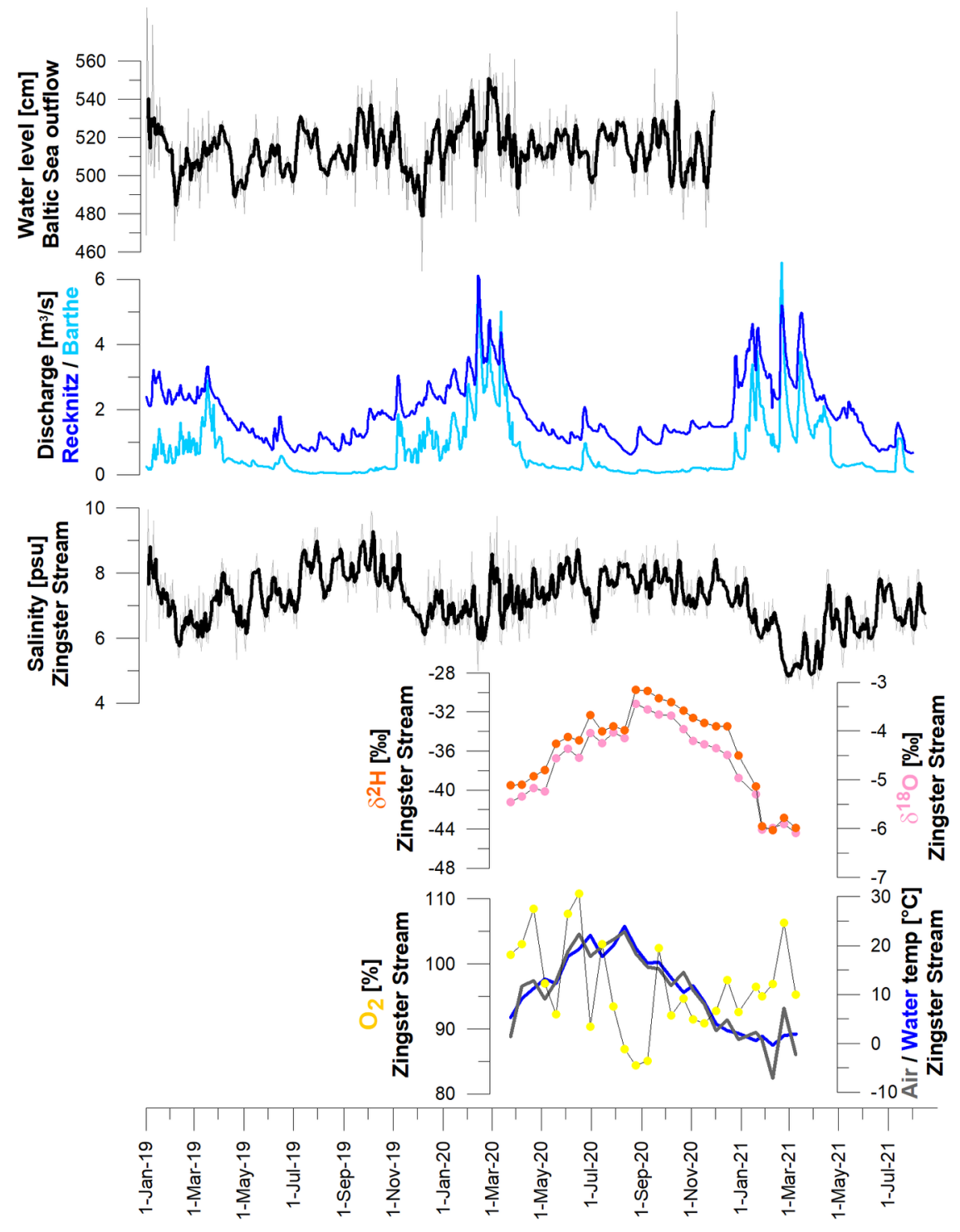

Fig. 4: Time series of $\delta^{2} \mathrm{H} / \delta^{18} \mathrm{O}$ values in water samples collected between $24^{\text {th }}$ March 2020 and $9^{\text {th }}$ March 2021 at Biological Station Zingst (Zingster Stream; sampling point E; Fig. 2b), in comparison to water temperature and long-term trends of salinity. Water level at the bodden outflow towards the Baltic Sea at Barhöft (WSV, 2022). Riverine discharge of Recknitz and Barthe (STALU, 2022) . 

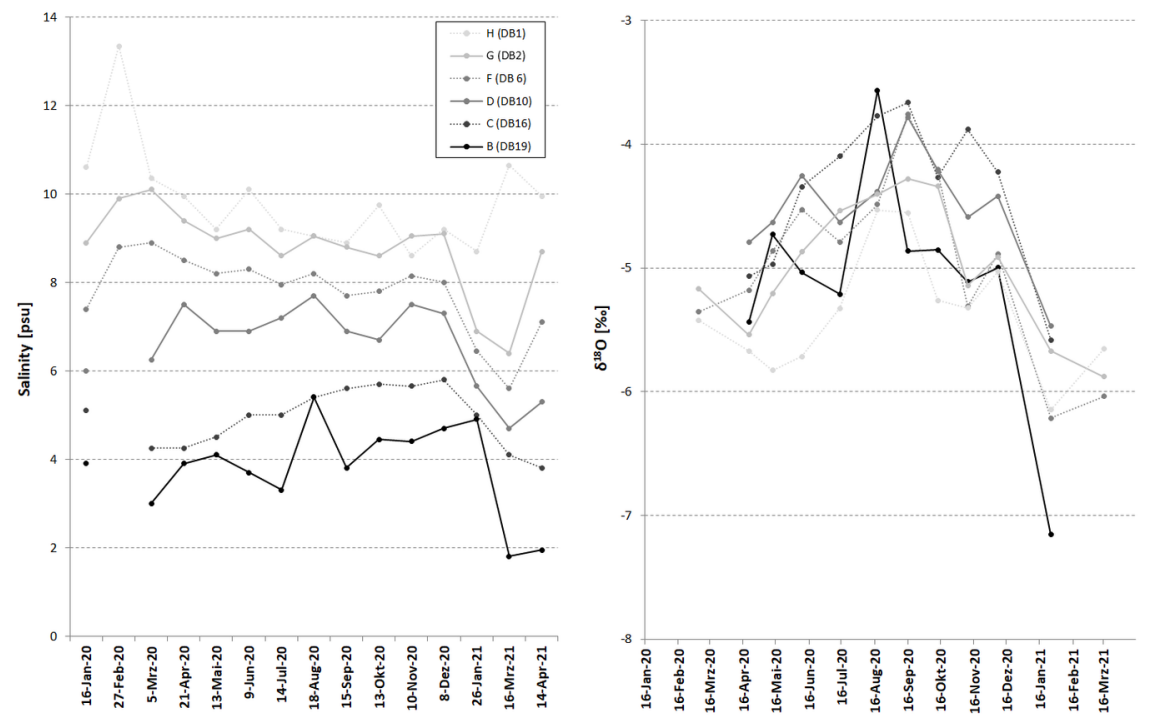

Fig. 5: Time series of a) salinity and b) $\delta^{2} \mathrm{H}$ values in water samples collected monthly at a transect along the Zingster Bodden chain, reaching from buoys located near the inflow of the river Recknitz (sampling spot B; LUNG monitoring point DB19) to those located close to the outflow towards the Baltic Sea (sampling spot H; LUNG monitoring point DB 1).

Vitter bodden (Hiddensee, Kloster)

The outermost Rügener boddens are characterised by complex dynamics within multiple influencing watermasses: water is partially intruding from the Baltic Sea, south and northeast of Hiddensee island (Bachor, 2005). Freshwater surface run off is derived from the NRBC (Helmut Hübel et al., 1998) (Fig. 6). The bodden is further susceptible to large-scale water exchange with eastward parts of the bodden coast, via the Strela Sound (Birr, 1988; U. Schiewer \& Gocke, 1996).

At Vitter Bodden (Hiddensee/Kloster; sampling point I), water isotope data exhibit similar seasonal trends than at the Schlei and DZBC sampling spots (Fig. 6). The salinity measurements showed variable values in the sampling period (18 ${ }^{\text {th }}$ March $2020-3^{\text {rd }}$ March 2021), ranging from 7.5 to 11.2 psu (Fig. 6). Similar as in the outer boddens of DZBC, salt water intrusion events (Fig. 3) are the reason behind maximum salinities in February 2020 and 2021. Fluctuating values at the end of the time series are probably influenced by the partial appearance and melting of an ice-cover across the boddens in February 2021. 

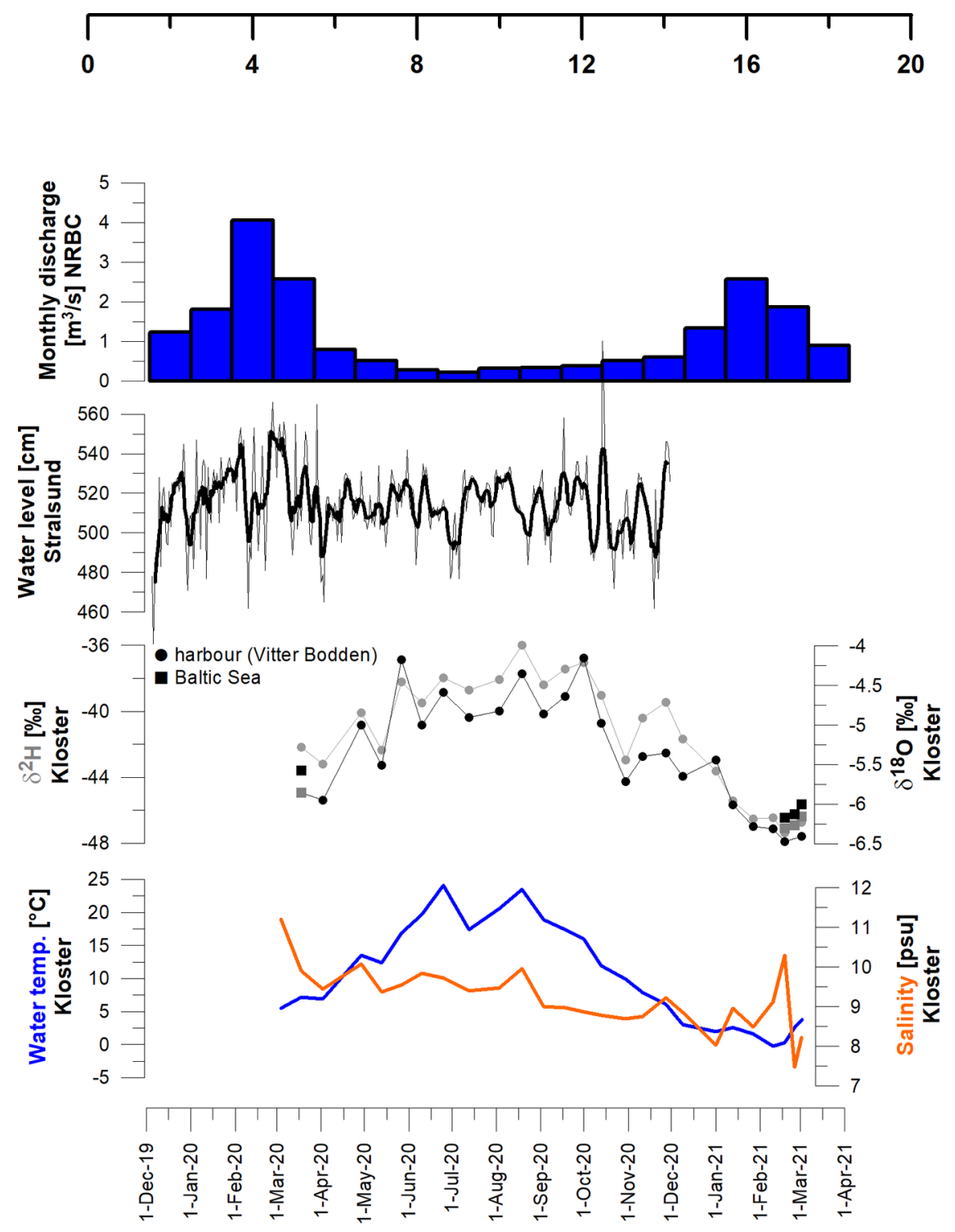

Fig. 6: Time series of $\delta^{2} \mathrm{H} / \delta^{18} \mathrm{O}$ values in water samples collected between $18^{\text {th }}$ March 2020 and $3^{\text {rd }}$ March 2021 at the ferry harbour Kloster, Hiddensee (Vitter Bodden; sampling point I), in comparison to salinity and water temperature. Water level from Strela Sound (Stralsund; point \#40) provided by WSV (WSV, 2022). Monthly surface flow data from NRBC to Vitter bodden (STALU, 2022).

\section{Control mechanisms on water isotopes and salinity}

Water samples collected at the A. P. Møller Skolen (Kleine Breite, Schlei; sampling point A), Biological Station Zingst (Zingster Stream, E), and Hiddensee/Kloster (Vitter bodden; I) all exhibit clear seasonal isotopic variability (Figs. 3-6). The seasonal isotope amplitude is in range of ca. $10-5\left(\delta^{18} \mathrm{O}\right)$, reaching minimum/maximum values in Feb/Mar and Sep/Oct, respectively. Thus we suggest, that time-series data even at sampling points in the outermost boddens still mainly reflect a delayed and attenuated precipitation signal, i.e. a seasonality pattern as previously observed in German rivers (Reckerth et al., 2017) and northern German lakes (B. Aichner et al., 2021) . Those trends in $\delta^{2} \mathrm{H}$ and $\delta^{18} \mathrm{O}$ values are not fully mirrored by seasonal salinity changes, especially in the inner Schlei $(A)$, the outer Zingster boddens $(\mathrm{F}-\mathrm{H})$, and the 
Vitter bodden (I).

This gives evidence, that other factors than mixing processes between freshwater and marine water masses, exhibit additional control on local water isotopes and salinity. For example, higher temperature and/or ${ }^{18} \mathrm{O}$ $/{ }^{2} \mathrm{H}$-enrichment due to evaporation from lagoon surfaces are potential drivers behind higher $\delta$-values in summers. This is plausible, since potential evaporation has been estimated to be in range of annual freshwater supply by precipitation, at least in the DZBC (Chubarenko et al., 2005). In winters, lower $\delta$-values were observed in Feb/March 2021 compared to Feb/March 2020. This could indeed be explained by temperature control, i.e. the generally more cold conditions with partially ice-cover on all sampling spots in winter / spring 2020/2021, compared to the relatively mild winter/spring 2019/2020 (reflected in water temperatures; Figs $3-5)$.

\subsection{Water isotopes along the Schlei and bodden transects}

Spatial trends

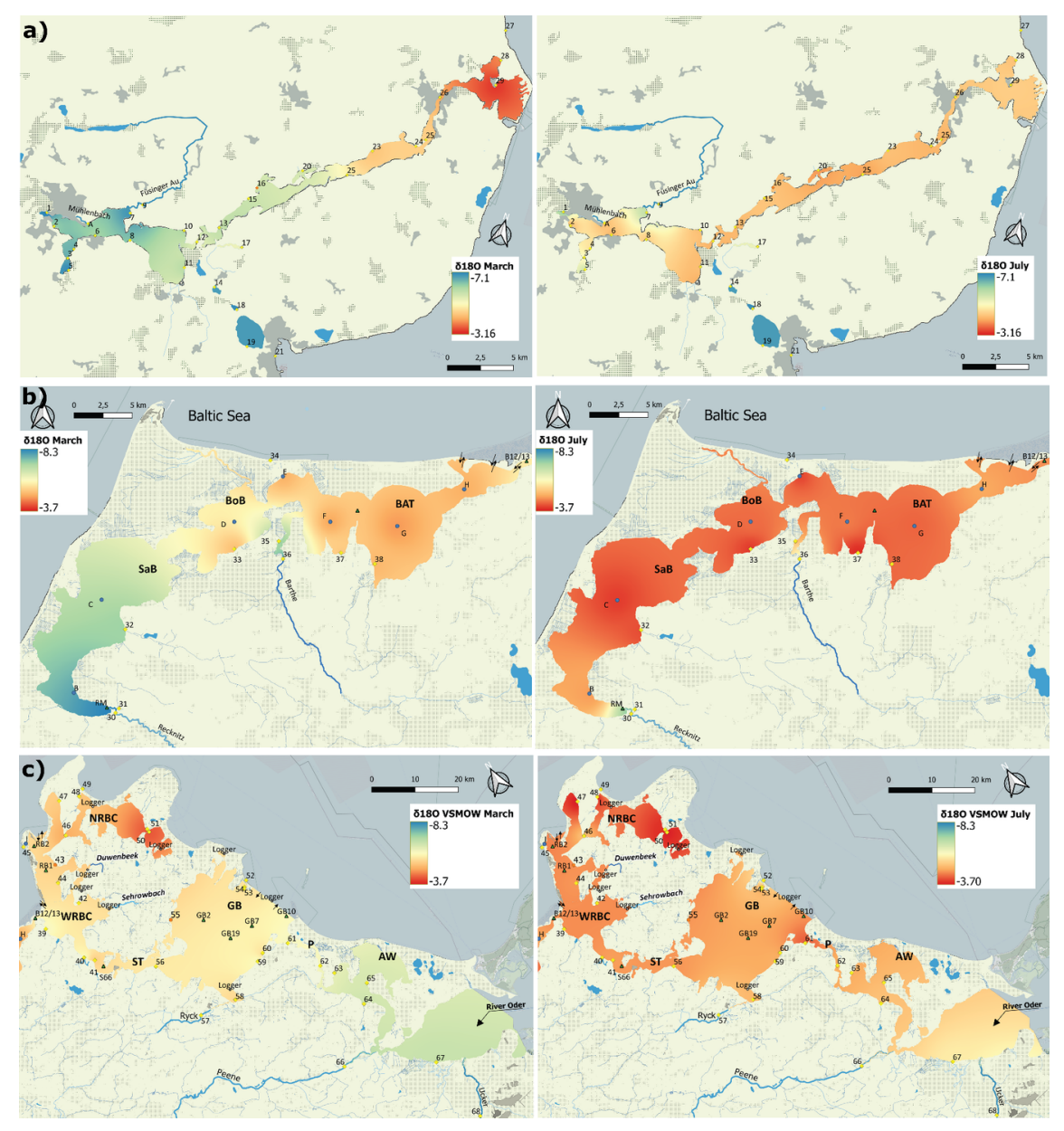

Fig. 7: Interpolated $\delta^{18} \mathrm{O}$ values along the three sampled transects for March (left) and July (right) 2020. Baltic Sea excluded from interpolation. Panels a - c refer to subregions as indicated in Figure 1. Circles A-I: sampling points for time-series. Circles \#1-68: shore samples. Arrows indicate exchange points with Baltic Sea water. Abbreviations as in Fig. 2.

Similar to salinity gradients (Fig. 2), the water isotope values in March 2020 increase from low to high at all three transects from river inlets to the outflows to the Baltic Sea (exemplarily plotted for $\delta^{18} \mathrm{O}$ values in 
Fig. 7). In July 2020, most regions show higher $\delta$-values compared to Spring (Fig. 7; interpolated maps with isotope offsets in Supplementary Fig S1). Especially, the innermost waterbodies, such as the inner Schlei, the Saaler Bodden at DZBC, and the NRBC, exhibit relatively strong increase of isotope values.

Exceptions from these trends are areas under direct influence of Baltic Sea water, such as the outflow regions of the Schlei and DZBC, which show lower $\delta$-values in July compared to March (Fig. 7). The latter can be explained by lower salinity and consequently lower isotope values of Baltic Sea water in summer, compared to the high values after the saltwater intrusion events in February and March 2020 (Fig. 3).

These dependencies lead to isotope gradients which are much less pronounced than in March. Specifically the DZBC shows almost homogenous isotope values along the whole bodden chain, with exception of the areas directly adjacent to river inflows (Fig. 7b). In the following, isotope-salinity correlations are closer examined.

Salinity - isotope correlation
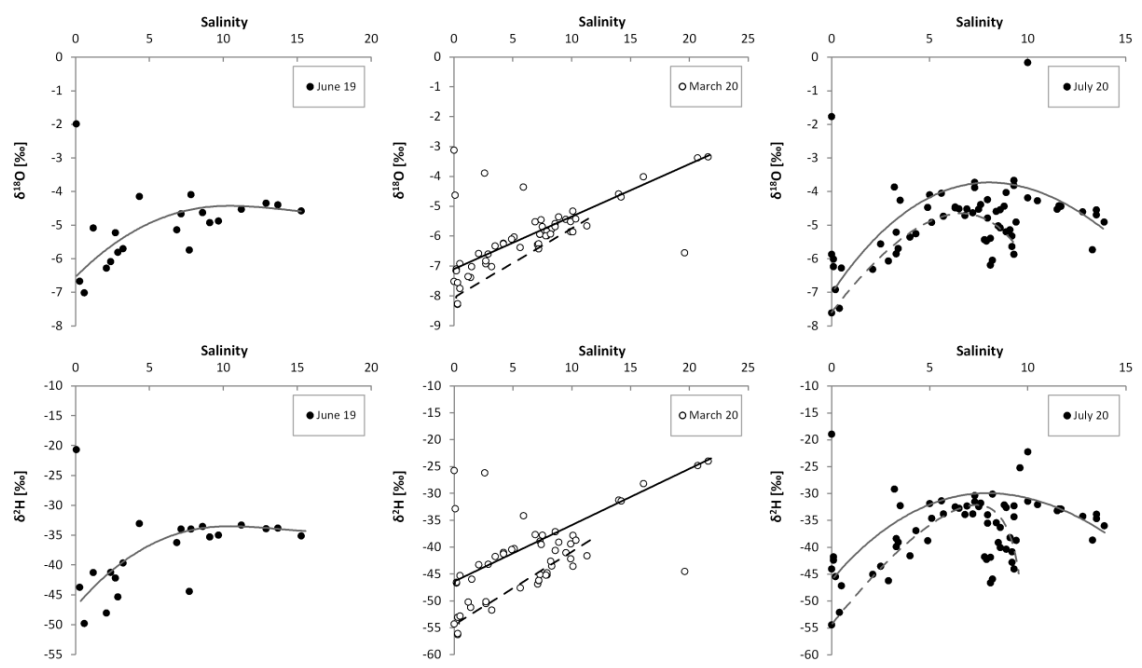

Fig. 8: Correlation between $\delta^{18} \mathrm{O}$ and $\delta^{2} \mathrm{H}$ values and salinity in June 2019, March 2020, and July 2020. Linear and hyperbolic trendlines for Schlei (solid) and combined Darß-Zingster and Rügener Bodden (dashed) samples, under exclusion of outliers as derived from lakes and the open Baltic Sea.

The spatial trends in water isotopes as visualized in Fig. 7 are illustrated as correlation crossplots between $\delta$-values and salinities in Fig. 8. Those reveal a positive correlation for samples from March 2020 (isotope amplitude ca. $30 \delta^{18} \mathrm{O}$ over ca. 20 salinity units). In contrast, samples from July 2020 reveal hyperbolic correlations between the two parameters (Fig. 8). Here, $\delta$-values reach a plateau of maximum values for salinities $>7$. For some samples, a reversal towards lower $\delta$-values with increasing salinities is observable. A similar trend is observable in samples from June 2019, which were taken in lower spatial resolution (Fig. 8). 

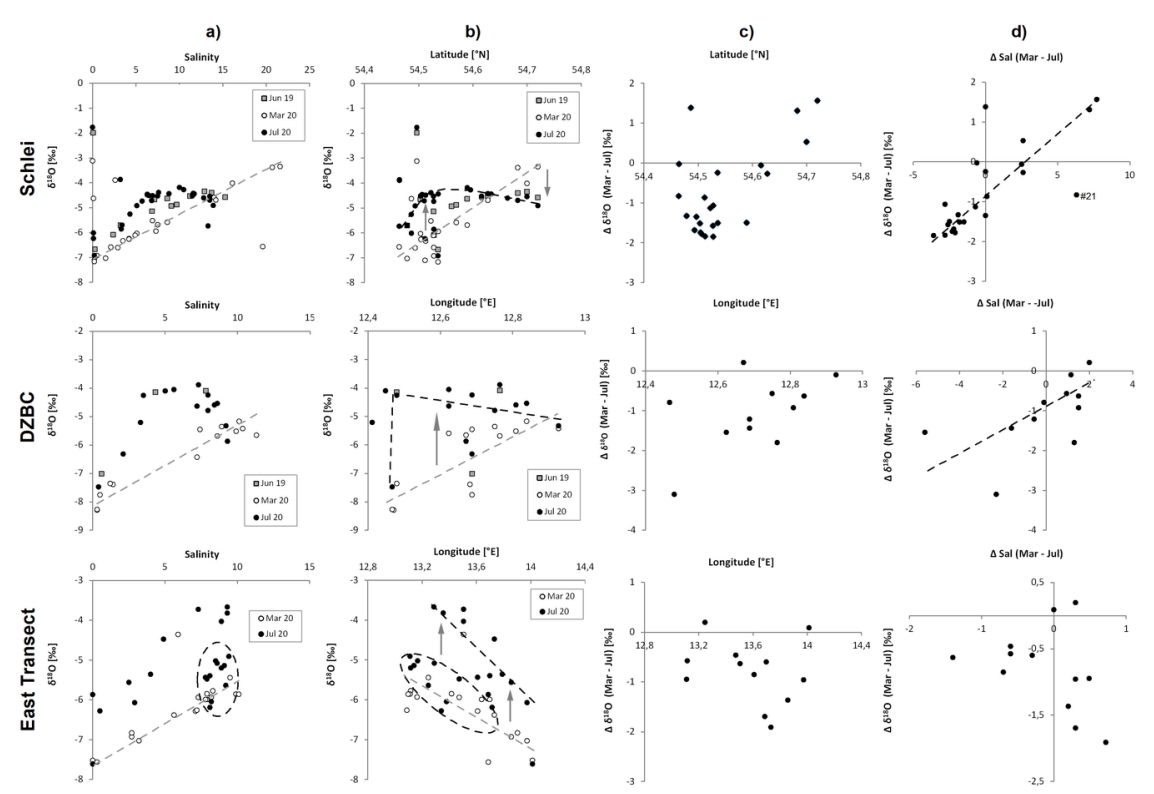

Fig. 9: Correlations between a) $\delta^{18} \mathrm{O}$ values and salinity. Dashed grey trendline for March 20. Dashed black circle indicate Rügener Bodden and Baltic Sea samples; b) $\delta^{18} \mathrm{O}$ values and latitude or longitude. Dashed grey/black trendlines for March/July 20. Grey arrows indicate direction of isotopic change from March to July; c) $\Delta \delta^{18} \mathrm{O}$ (March - July) and latitude or longitude; d) $\Delta \delta^{18} \mathrm{O}$ and $\Delta$ Sal (March - July) for the three sampled transects. DZBC: Darß-Zingst Bodden Chain. East Transect comprises Stettiner Haff to GW Bodden and Rügener Boddens.

When analysing the three transects individually and in more detail, they all show a significant correlation between isotope values and salinity in March 2020 (Fig. 9a). Especially in the Schlei, an almost linear correlation between $\delta$-values and salinity is observable. Outliers with significant higher $\delta$-values are samples taken from adjacent lakes and noors, which not or only weakly connected to the Schlei (Bültsee \#14, Schnaaper See \#21, Ornumer Noor \#17, and Windebyer Noor \#19) (Fig. 7a). Further, a sample from the close-by Baltic Sea location Eckernförde (\#21) might be influenced by local mixing process different than in the Schlei system and its adjacent Baltic Sea outflow (e.g. \#27, \#29). In the DZBC, the March 2020 samples can be assigned to two clusters: 1) low saline samples taken from rivers or close to their outflows (\#30/\#31, \#35/\#36) and from Saaler Bodden (\#32). 2) samples with salinity $>6$ psu from all other locations (Fig. 9a and $7 \mathrm{~b}$ ). In the Eastern Transect, again a linear salinity - isotope correlation is observed from the Stettiner Haff to Rügener Boddens, with one outlier (\#51) derived from the inner NRBC (Fig. 9a and 7c).

In contrast, in the Schlei and DCBZ, the two sampled summers (June 2019 and July 2020), reveal constant isotope values or even a reverse correlation from salinities 4-6 psu and higher on (Fig. 9a). In the eastern transect, however, a positive correlation along the Stettiner Haff-Peenestrom-Greifswalder Bodden transect is observable, while samples from the WRBC, NRBC and adjacent Baltic Sea samples show mixed values clustering around -4.9 to -6.2 salinity values 8.1 to $9.6 \mathrm{psu}$ (dashed black circles in Fig. 9a and b).

These patterns come out more clearly when correlating $\delta$-values to latitude / longitude, following their geographical orientations along the transects (Fig. 9b), especially when considering the March-July offset of isotope values $(\Delta \delta)$ (Fig. 9c). This approach eliminates the influence of larger salinity ranges in March compared to July, which is strongest in the Schlei, and makes isotope values from specific spots better comparable.

As noted above, most samples show isotope enrichment in the warmer season (i.e. negative $\Delta \delta$ March-July values) (Fig. 7). Exceptions are a number of samples from the Baltic Sea, whose isotope signatures are 
rather driven by mixing processes than by seasonal trends, or samples under direct influence of Baltic Sea water (e.g. close to the outflows of the Schlei and DZBC). In general, samples tendencially show stronger isotope enrichment further inlands. Thus, they show increasing $\Delta \delta$ (March-July) values from the rivers inflow towards the Baltic Sea (Fig 9b, c; Fig. 7; interpolated salinity and $\Delta \delta$ maps in Supplementary Figure S1). Obviously, the shallow lagoons inlands (such as Kleine Breite at the Schlei, and Saaler and Bodstedter Boddens at DZBC) are more susceptible to undergo stronger isotopic enrichment in summers, than locations more adjacent to the Baltic Sea. This is most pronounced in the Schlei, here the $\Delta \delta$ values are balanced (i.e. similar isotope values in March and July) at ca. $75 \%$ of the distance between the inner Schlei and the outflow towards the Baltic Sea (Fig. 9c). Beyond this place (which lies around the narrow passage aside the town Arnis, \#24/\#25), $\Delta \delta$ values become even positive due to lower $\delta$-values in July compared to March. (Fig. 7a and Supplementary Figure S1a).

The major inference from these data set is, that sampling points that undergo larger salinity changes between the maximum and minimum freshwater inflows in spring and summers (i.e. most negative $\Delta$ Sal Mar-Jul) are also more susceptible to larger isotopic enrichment in the summers (more negative $\Delta \delta$ values Mar-Jul). This systematic is most pronounced in the Schlei, which is characterized by the most linear salinity gradient among the studied transects (Fig. 9d). A similar trend is visible in the DZBC, but here it is weakened due to outliers as mainly derived from the Barther Bodden and Grabow samples. In the Eastern transect, no clear systematics between $\Delta$ Sal and $\Delta \delta$ could be observed. While almost all samples show isotopic enrichment in summers (negative $\Delta \delta$ ), the stronger influence of mixing processes of multiple water sources (i.e. from rivers, inner Rügen boddens, Baltic Sea water intrusion from both the east and the north-west) can explain the heterogenous isotope values in this study area. Here, increasing sample density along sub-transects could potentially facilitate interpretation of isotope data and the control mechanisms behind.

\section{Conclusions}

The time series data show that the studied estuarine systems exhibit a clear seasonality within their water isotope values, which is comparable NE German lakes rivers in both isotope amplitude and time succession. The transect data further reveal complex isotope vs salinity correlations: widely positive linear correlations were observed in March 2020 along all transects. In contrast, hyperbolic and partially inverse correlations were found in the two samples summers (June 2019 and July 2020).

We hypothesize that this is triggered by increased susceptibility of the mostly shallow inland water to evaporative isotope enrichment in summers, causing higher $\delta$-values. Further, the discharge regime of tributary rivers (lower $\delta$-values) and influence of water intrusion from the Baltic Sea (higher $\delta$-values) obviously plays a role.

In summary, salinity is a fairly good predictor for water isotopes on larger spatial scales. On regional scales, local effects overprint the positive correlation between the two parameters especially in summers, partly even leading to negative correlations. This seasonality of salinity vs isotope correlation needs to be considered when interpreting biogenic isotope data (of plants or animals) because those might be similarly seasonally biased (often towards the warm/growing season).

\section{Acknowledgements}

Funding was provided by German Research Foundation (DFG) to B.A. (grant Ai 134/3-1). We are grateful to Volker Reiff, Henry Hansen and Jan Droll for help with sampling.

\section{Data availability}

All isotope and water chemical parameters in this manuscript are available at PANGAEA (Aichner et al., 2021): https://doi.org/10.1594/PANGAEA.937990

Until acceptance of the manuscript, this temporary and barrier free link can be used to access the data set: https://doi.pangaea.de/10.1594/PANGAEA.937990

\section{References}


Aichner, B., Dubbert, D., Kiel, C., Kohnert, K., Ogashawara, I., Jechow, A., . . . Berger, S. A. (2021). Spatial and seasonal patterns of water isotopes in northeastern German lakes. Earth Syst. Sci. Data Discuss., 2021 , 1-24. doi:10.5194/essd-2021-315

Aichner, B., Hilt, S., Périllon, C., Gillefalk, M., \& Sachse, D. (2017). Biosynthetic hydrogen isotopic fractionation factors during lipid synthesis in submerged aquatic macrophytes: effect of groundwater discharge and salinity. Organic Geochemistry, 113, 10-16.

Aichner, B., Makhmudov, Z. M., Rajabov, I., Zhang, Q., Pausata, F. S. R., Werner, M., . . Mischke, S. (2019). Hydroclimate in the Pamirs Was Driven by Changes in Precipitation Evaporation Seasonality Since the Last Glacial Period. Geophysical Research Letters, 46 , 13972-13983.

Aron, P. G., Levin, N. E., Beverly, E. J., Huth, T. E., Passey, B. H., Pelletier, E. M., . . Yarian, D. A. (2021). Triple oxygen isotopes in the water cycle. Chemical Geology, 565 . doi:10.1016/j.chemgeo.2020.120026

Bachor, A. (2005). Nährstoff- und Schwermetallbilanzen der Küstengewässer Mecklenburg-Vorpommerns unter besonderer Berücksichtigung ihrer Sedimente. Landesamt für Umwelt, Naturschutz und Geologie. Greifswald.

Barrie, G. M., Worden, R. H., Barrie, C. D., \& Boyce, A. J. (2015). Extensive evaporation in a modern temperate estuary: Stable isotopic and compositional evidence. Limnology and Oceanography, 60 (4), 12411250. doi:10.1002/lno.10091

Benetti, M., Reverdin, G., Aloisi, G., \& Sveinbjornsdottir, A. (2017). Stable isotopes in surface waters of the Atlantic Ocean: Indicators of ocean-atmosphere water fluxes and oceanic mixing processes. Journal of Geophysical Research-Oceans, 122 (6), 4723-4742. doi:10.1002/2017jc012712

Birr, H.-D. Hydrographische Charakteristik und Umweltprobleme der mecklenburg-vorpommerschen Boddengewässer. Greifswalder Geographische Arbeiten 14, 111-128.

Birr, H.-D. (1988). Zu den Strömungsverhältnissen des Strelasundes. .Beiträge zur Meereskunde, 58 , 3-8.

Bittar, T. B., Berger, S. A., Birsa, L. M., Walters, T. L., Thompson, M. E., Spencer, R. G. M., . . Brandes, J. A. (2016). Seasonal dynamics of dissolved, particulate and microbial components of a tidal saltmarshdominated estuary under contrasting levels of freshwater discharge. Estuarine Coastal and Shelf Science, 182 , 72-85. doi:10.1016/j.ecss.2016.08.046

Bowen, G. J., \& Revenaugh, J. (2003). Interpolating the isotopic composition of modern meteoric precipitation. Water Resources Research, 39 (10). doi:10.1029/2003wr002086

Brennan, S. R., Cline, T. J., \& Schindler, D. E. (2019). Quantifying habitat use of migratory fish across riverscapes using space-time isotope models. Methods in Ecology and Evolution, 10 (7), 1036-1047. doi:10.1111/2041-210x.13191

Chamberlayne, B. K., Tyler, J. J., \& Gillanders, B. M. (2021). Controls Over Oxygen Isotope Fractionation in the Waters and Bivalves (Arthritica helmsi) of an Estuarine Lagoon System. Geochemistry Geophysics Geosystems, 22 (6). doi:10.1029/2021GC009769

Chubarenko, B., Chubarenko, I., \& Baudler, H. (2005). Comparison of Darss-Zingst Bodden Chain and Vistula Lagoon (Baltic Sea) in a view of hydrodynamic numerical modelling. Baltica, 18 .

Correns, M. (1977). Grundzüge von Hydrographie und Wasserhaushalt der Boddengewässer an der Küste der Deutschen Demokratischen Republik.Acta Hydrochimica Et Hydrobiologica, 5 , 517-526.

Correns, M., \& Jäger, F. (1979). Beiträge zur Hydrographie der Nordrügenschen Bodden. I. Einführung in das Untersuchungsgebiet, Wasserstandsverhältnisse und Wasserhaushalt. Acta Hydrophysica 23 , 149-177.

Craig, H. (1961). Isotopic Variations in Meteoric Waters. Science, 133 (346), 1702-\&. doi:DOI 10.1126/science.133.3465.1702 
Craig, H., \& Gordon, L. I. (1965). Deuterium and oxygen 18 variations in the ocean and marine atmosphere . In: Proceedings of a conference on stable isotopes in oceanographic studies and palaeo temperatures. Spoleto Italy, pp 9-130.

Cyberski, J., Wróblewski, A., \& Stewart, J. (2000). Riverine water inflows and the Baltic Sea water volume 1901-1990. Hydrol. Earth Syst. Sci., 4 (1), 1-11. doi:10.5194/hess-4-1-2000

Dansgaard, W. (1964). Stable Isotopes in Precipitation. Tellus, 16 (4), 436-468.

Dietzel, M., Tang, J., Leis, A., \& Köhler, S. J. (2009). Oxygen isotopic fractionation during inorganic calcite precipitation - Effects of temperature, precipitation rate and pH. Chemical Geology, 268 (1), 107-115. https://doi.org/10.1016/j.chemgeo.2009.07.015

Dutton, A., Wilkinson, B. H., Welker, J. M., Bowen, G. J., \& Lohmann, K. C. (2005). Spatial distribution and seasonal variation in $\mathrm{O}-18 / \mathrm{O}-16$ of modern precipitation and river water across the conterminous USA.Hydrological Processes, 19 (20), 4121-4146. doi:10.1002/hyp.5876

Ehhalt, D. H. (1969). On the deuterium-salinity relationship in the Baltic Sea. Tellus A, 21 , 429-435.

Frew, R. D., Dennis, P. F., Heywood, K. J., Meredith, M. P., \& Boswell, S. M. (2000). The oxygen isotope composition of water masses in the northern North Atlantic. Deep-Sea Research Part I-Oceanographic Research Papers, 47 (12), 2265-2286. doi:10.1016/S0967-0637(00)00023-6

Frohlich, K., Grabczak, J., Rowski, K. (1988). Deuterium and oxygen-18 in the baltic sea. Chemical Geology: Isotope Geoscience Section, 72, 77-83.

Funkel, C. (2004). Jeschke, Lebrecht; Lenschow, Uwe; Zimmermann, Horst (Red.): Die Naturschutzgebiete in Mecklenburg-Vorpommern.Naturschutz im Land Sachsen-Anhalt, 41 (1), 60-62.

Gat, J. R., Gonfiantini, R., \& (Eds). (1981). Stable Isotope Hydrology: Deuterium and Oxygen-18 in the Water Cycle. (Vol. 210). Vieanna: IAEA.

Gocke, K., Rheinheimer, G., \& Schramm, W. (2003).Hydrographische, chemische und mikrobiologische Untersuchungen im Langsprofil der Schlei. Schriften des Naturwissenschaftlichen Vereins fur Schleswig-Holstein, $68,31-62$.

Grupe, G., Heinrich, D., \& Peters, J. (2009). A brackish water aquatic foodweb: trophic levels and salinity gradients in the Schlei fjord, Northern Germany, in Viking and medieval times. Journal of Archaeological Science, 36 , 2125-2144. doi:10.1016/j.jas.2009.05.011

Haggi, C., Chiessi, C. M., \& Schefuss, E. (2015). Testing the D / H ratio of alkenones and palmitic acid as salinity proxies in the Amazon Plume. Biogeosciences, 12 , 7239-7249.

Halder, J., Terzer, S., Wassenaar, L. I., Araguas-Araguas, L. J., \& Aggarwal, P. K. (2015). The Global Network of Isotopes in Rivers (GNIR): integration of water isotopes in watershed observation and riverine research. Hydrology and Earth System Sciences, 19 (8), 3419-3431. doi:10.5194/hess-19-3419-2015

Harwood, A. J. P., Dennis, P. F., Marca, A., Pilling, G. M., \& Millner, R. S. (2008). The oxygen isotope composition of water masses within the North Sea. Estuarine Coastal and Shelf Science, 78 , 353-359.

He, D., Nemiah Ladd, S., Saunders, C. J., Mead, R. N., \& Jaffe, R. (2020). Distribution of n-alkanes and their $\delta 2 \mathrm{H}$ and $\delta 13 \mathrm{C}$ values in typical plants along a terrestrial-coastal-oceanic gradient.Geochimica Et Cosmochimica Acta .

Hübel, H., \& Dahlke, S. (1999). Die Nordrügenschen Boddengewässer-Entwicklung in Vergangenheit. Gegenwart und Zukunft.Bodden, 7 , 137-156.

Hübel, H., Wolff, C., \& Meyer-Reil, L.-A. (1998). Salinity, Inorganic Nutrients, and Primary Production in a Shallow Coastal Inlet in the Southern Baltic Sea (Nordrügenschen Bodden) Results from 
Long-Term Observations (1960-1989). International Review of Hydrobiology, 83 (5-6), 479-499. https://doi.org/10.1002/iroh.19980830516

Ingram, B. L., Conrad, M. E., \& Ingle, J. C. (1996). Stable isotope and salinity systematics in estuarine waters and carbonates: San Francisco Bay. Geochimica Et Cosmochimica Acta, 60 (3), 455-467. doi:10.1016/00167037(95)00398-3

Jasechko, S., Kirchner, J. W., Welker, J. M., \& McDonnell, J. J. (2016). Substantial proportion of global streamflow less than three months old. Nature Geoscience, 9 (2), 126-129. doi:10.1038/ngeo2636

Jefanova, O., Mazeika, J., Petrpaius, R., Skuratovj, Paskauskas, R., Martma, T., . . . Ezhova, E. (2020). Baltic Sea water tritium and stable isotopes in 2016-2017. Isotopes in Environmental and Health Studies, 56 , $193-204$.

Ladd, S. N., \& Sachs, J. P. (2015). Hydrogen isotope response to changing salinity and rainfall in Australian mangroves. Plant, cell 83 environment, 3812 , 2674-2687.

Ladd, S. N., \& Sachs, J. P. (2017). 2 H/ 1 H fractionation in lipids of the mangrove Bruguiera gymnorhiza increases with salinity in marine lakes of Palau. Geochimica Et Cosmochimica Acta, 204 , 300-312.

Lampe, R. (1999). The Odra Estuary as a filter and transformation area.Acta Hydrochimica Et Hydrobiologica, 27 , 292-297.

Leduc, G., Sachs, J. P., Kawka, O. E., \& Schneider, R. R. (2011). Holocene changes in eastern equatorial Atlantic salinity as estimated by water isotopologues. Earth and Planetary Science Letters, 362 , 151-162.

Li, H., Liu, X., Tripati, A., Feng, S., Elliott, B., Whicker, C., . . Kelley, A. M. (2020). Factors controlling the oxygen isotopic composition of lacustrine authigenic carbonates in Western China: implications for paleoclimate reconstructions. Scientific Reports, 10 (1), 16370. doi:10.1038/s41598-020-73422-4

LLUR. (2022). Discharge data Füsinger Au 2019-2021 . Landesamt für Landwirtschaft, Umwelt und ländliche Räume Schleswig-Holstein, Flintbek. Retrieved from: https://opendata.schleswigholstein.de/dataset/abfluss-pegel-fusing-fusinger-au

LLUR. (2001). Ergebnisse langjähriger Wasserunteruntersuchungen in der Schlei. Eine Informations- und Planungsgrundlage. Landesamt für Landwirtschaft, Umwelt und ländliche Räume Schleswig-Holstein, Flintbek.

Maloszewski, P., Rauert, W., Trimborn, P., Herrmann, A., \& Rau, R. (1992). Isotope Hydrological Study of Mean Transit Times in an Alpine Basin (Wimbachtal, Germany). Journal of Hydrology, 140 (1-4), 343-360. doi:10.1016/0022-1694(92)90247-S

Matta, M. E., Black, B. A., \& Wilderbuer, T. K. (2010). Climate-driven synchrony in otolith growthincrement chronologies for three Bering Sea flatfish species. Marine Ecology Progress Series, 413 , 137-145. doi: $10.3354 / \operatorname{meps} 08689$

McGuire, K. J., McDonnell, J. J., Weiler, M., Kendall, C., McGlynn, B. L., Welker, J. M., \& Seibert, J. (2005). The role of topography on catchment-scale water residence time. Water Resources Research, 41 (5). doi:10.1029/2004wr003657

Meer, M. T. J., Baas, M., Rijpstra, W. I. C., Marino, G., Rohling, E. J., Damsté, J. S. S., \& Schouten, S. (2007). Hydrogen isotopic compositions of long-chain alkenones record freshwater flooding of the Eastern Mediterranean at the onset of sapropel deposition. Earth and Planetary Science Letters, 262 , 594-600.

Mohan, J. A., \& Walther, B. D. (2015). Spatiotemporal Variation of Trace Elements and Stable Isotopes in Subtropical Estuaries: II. Regional, Local, and Seasonal Salinity-Element Relationships.Estuaries and Coasts, 38 (3), 769-781. doi:10.1007/s12237-014-9876-4 
Mohrholz, V. (2018). Baltic saline barotropic inflows (SBI) 1887 - 2018. dataset 2019-2021. doi: 10.12754/data-2018-0004

Mohrholz, V. (2018). Major Baltic Inflow Statistics - Revised.Frontiers in Marine Science . 5 , 384. doi: 10.3389 /fmars.2018.00384

Ogrinc, N., Kanduc, T., Stichler, W., \& Vreca, P. (2008). Spatial and seasonal variations in delta O-18 and delta D values in the River Sava in Slovenia. Journal of Hydrology, 359 (3-4), 303-312. doi:10.1016/j.jhydrol.2008.07.010

Orlowski, N., Kraft, P., Pferdmenges, J., \& Breuer, L. (2016). Exploring water cycle dynamics by sampling multiple stable water isotope pools in a developed landscape in Germany. Hydrology and Earth System Sciences, 20 (9), 3873-3894. doi:10.5194/hess-20-3873-2016

Patterson, W. P., Smith, G. R., \& Lohmann, K. C. (1993). Continental paleothermometry and seasonality using the isotopic composition of aragonitic otoliths of freshwater fishes. GMS, 78 , 191-202.

Price, R. M., Skrzypek, G., Grierson, P. F., Swart, P. K., \& Fourqurean, J. W. (2012). The use of stable isotopes of oxygen and hydrogen to identify water sources in two hypersaline estuaries with different hydrologic regimes. Marine and Freshwater Research, 63 (11), 952-966. doi:10.1071/Mf12042

Quay, P. D., Wilbur, D., Richey, J. E., Devol, A. H., Benner, R., \& Forsberg, B. R. (1995). The 18O:16O of dissolved oxygen in rivers and lakes in the Amazon Basin: Determining the ratio of respiration to photosynthesis rates in freshwaters. Limnology and Oceanography, 40 (4), 718-729. https://doi.org/10.4319/lo.1995.40.4.0718

Reckerth, A., Stichler, W., Schmidt, A., \& Stumpp, C. (2017). Long-term data set analysis of stable isotopic composition in German rivers. Journal of Hydrology, 552 , 718-731. doi:10.1016/j.jhydrol.2017.07.022

Richter, W. v., \& Kowski, P. (1990). Deuterium and Oxygen-18 in Surface Waters of GDR draining to the Baltic Sea. Isotopes in Environmental and Health Studies, 26 , 569-573.

Rodgers, P., Soulsby, C., Waldron, S., \& Tetzlaff, D. (2005). Using stable isotope tracers to assess hydrological flow paths, residence times and landscape influences in a nested mesoscale catchment.Hydrology and Earth System Sciences, 9 (3), 139-155. doi:10.5194/hess-9-139-2005

Sachs, J. P., \& Schwab, V. F. (2011). Hydrogen isotopes in dinosterol from the Chesapeake Bay estuary. Geochimica Et Cosmochimica Acta, 75 , 444-459.

Schiewer, U. (2008). Ecology of Baltic coastal waters . Ecological Studies 147. Springer, Berlin.

Schiewer, U., \& Gocke, K. (1996). Ökologie der Bodden und Förden. In G. Rheinheimer (Ed.), Meereskunde der Ostsee. (pp. 216-221.): Springer, Berlin.

Schouten, S., Ossebaar, J., Schreiber, K., Kienhuis, M. V. M., Langer, G., Benthien, A., \& Bijma, J. (2006). The effect of temperature, salinity and growth rate on the stable hydrogen isotopic composition of long chain alkenones produced by Emiliania huxleyi and Gephyrocapsa oceanica. Biogeosciences, 3 , 113-119.

Schulz, H. (1979). Ein numerisches Modell des Wasserhaushalts und der Wasserbeschaffenheit in der Ostseebucht Schlei. Senckenbergiana maritima, 11 , 175-192.

Schumann, R., Baudler, H., Glass, Ä., Dümcke, K., \& Karsten, U. (2006). Long-term observations on salinity dynamics in a tideless shallow coastal lagoon of the Southern Baltic Sea coast and their biological relevance. Journal of Marine Systems, 60 , 330-344.

Schwarzer, K., Ricklefs, K., Bartholomä, A., \& Zeiler, M. (2008). Geological development of the North Sea and the Baltic Sea. Die Küste, 74, 1-17.

Seiß, G. (2014). Impact of Sea Level Change on Inner Coastal Waters of the Baltic Sea. Bundesanstalt für Wasserbau, Karlsruhe. 
Sklash, M. G., Farvolden, R. N., \& Fritz, P. (1976). Conceptual-Model of Watershed Response to Rainfall, Developed through Use of Oxygen-18 as a Natural Tracer. Canadian Journal of Earth Sciences, 13 (2), 271-283. doi:10.1139/e76-029

STALU. (2022). Discharge rates of Mecklenburg-Vorpommern rivers 2019-2021. Staatliche Ämter für Landwirtschaft und Umwelt Mecklenburg-Vorpommern, Stralsund .

Swart, P. K., \& Price, R. (2002). Origin of salinity variations in Florida Bay. Limnology and Oceanography, 47 (4), 1234-1241. doi:10.4319/lo.2002.47.4.1234

Torniainen, J., Lensu, A., Vuorinen, P. J., Sonninen, E., Keinänen, M., Jones, R. I., . . Kiljunen, M. (2017). Oxygen and carbon isoscapes for the Baltic Sea: Testing their applicability in fish migration studies.Ecology and Evolution, 7 , 2255 - 2267.

Trueman, C. N., Mackenzie, K. M., \& Palmer, M. R. (2012). Identifying migrations in marine fishes through stable-isotope analysis. Journal of fish biology, 81 (2), 826-847. doi:10.1111/j.1095-8649.2012.03361.x

WSV. (2022). Baltic Sea water level data. Wasserstraßen und Schifffahrtsverwaltung des Bundes. Lübeck.

Zanden, H. B. V., Soto, D. X., Bowen, G. J., \& Hobson, K. A. (2016). Expanding the Isotopic Toolbox: Applications of Hydrogen and Oxygen Stable Isotope Ratios to Food Web Studies. Frontiers in Ecology and Evolution, 4 . 